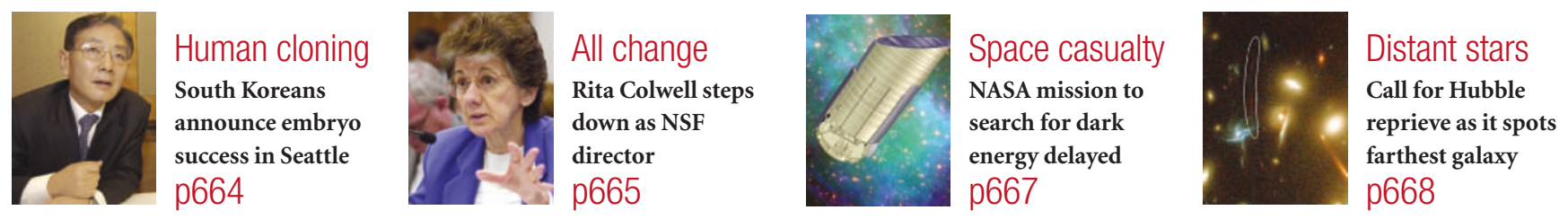

\title{
Publishers split over response to US trade embargo ruling
}

Geoff Brumfiel, Washington

Iranians struggling to secure free speech at home are facing a fresh set of restrictions from the US government.

The US Department of the Treasury has ruled that editing or publishing scientific manuscripts from Iran, Libya, Sudan and Cuba violates the trade embargo on these countries. And US publishers and scientific societies are divided over how to respond.

At a meeting in Washington on 9 February, David Mills, the treasury official in charge of implementing the policy, told representatives of 30 publishers that anyone wanting to publish papers from Iran should seek a licence from the treasury department. He also suggested that US scientists collaborating with Iranians could be prosecuted.

The ruling has split US scientific societies. The journals of the Institute of Electrical and Electronics Engineers (IEEE) have stopped accepting manuscripts from researchers in embargoed countries. On the other hand, the American Institute of Physics (AIP), the American Physical Society and the American Association for the Advancement of Science, which publishes
Science, have so far refused to comply. "We feel that we are protected by freedom of speech," says Marc Brodsky, executive director at the AIP.

Questions about interactions with Iran first arose in 2001 when the IEEE tried to rent a conference room at a Tehran meeting, and was told that this would violate the US trade embargo. In ensuing conversations between the organization and the treasury department's Office of Foreign Assets Control, it emerged that publishing could also be restricted. According to a 30 September 2003 letter from the office, editing content from an

\section{Scientists slam Bush record}

Geoff Brumfiel, Washington

Nearly two dozen Nobel laureates and 40 other leading researchers have signed an angry statement accusing the Bush administration of "misrepresenting and suppressing scientific knowledge".

The statement, due to be released this week, accuses the administration of stacking scientific committees, censoring results and dissolving advisory panels.

"The systematic, pervasive nature of these practices is unprecedented," says Kurt Gottfried, a particle physicist at Cornell
University and chairman of the Union of Concerned Scientists, which assembled the petition. "The very ethos of science is being challenged," he says.

Signatories include David Baltimore, president of the California Institute of Technology, Harold Varmus, former director of the National Institutes of Health, and Lewis Branscomb, professor of public policy at Harvard University and an adviser to both Republican and Democratic administrations.

www.ucsusa.org author in a restricted country is "prohibited ... unless specificallylicensed".

As a result, the IEEE's 100plus journals began declining manuscripts from researchers in Iran, Cuba, Libya and Sudan. "We felt we needed to operate within the laws of the country we are in," says Michael Lightner of the IEEE. This year, the American Nuclear Society, the American Chemical Society and the American Society for Microbiology followed suit (see Nature Med. 10, 109; 2004). Some of these societies, including the IEEE, are actively pursuing a licence to publish.

But other groups may seek to overturn the ruling. "The government should not be in the business of restricting this kind of firstamendment activity," says Allan Adler, head of legal and government affairs at the Association of American Publishers, which represents most major for-profit and society publishers in the United States, including the IEEE.

Adler says that the law specifically exempts 'information and informational materials' from trade embargoes. The association is considering several options, including court action and legislation, to overturn the ruling. "We think that this is wrong as a matter of law and a matter of principle," he says.

Nature and other publications of the Nature Publishing Group are still accepting manuscripts from the affected countries. "We see no grounds to absolutely decline to handle papers from these countries," says Philip Campbell, editor of Nature. "But we are taking legal advice."

Iranian scientists say that the US policy is crippling their research. "The ruling makes publication by Iranians in journals published in the United States practically impossible," says Fredun Hojabri, an Iranian chemist now living in San Diego, who heads the Sharif University of Technology Association, representing alumni, students and faculty of Iran's premier technical university. 